\title{
Microalgal Biostimulants and Biofertilisers in Crop Productions
}

\author{
Domenico Ronga ${ }^{1, *} \mathbb{C}$, Elisa Biazzi ${ }^{1}$, Katia Parati ${ }^{2}$, Domenico Carminati ${ }^{1}$, Elio Carminati ${ }^{1}$ and \\ Aldo Tava ${ }^{1}$ (iD \\ 1 CREA Research Centre for Animal Production and Aquaculture, viale Piacenza 29, 26900 Lodi, Italy; \\ elisa.biazzi@crea.gov.it (E.B.); domenico.carminati@crea.gov.it (D.C.); elio.carminati@crea.gov.it (E.C.); \\ aldo.tava@crea.gov.it (A.T.) \\ 2 Istituto Sperimentale Italiano Lazzaro Spallanzani, Loc. La Quercia, 26027 Rivolta d'Adda (CR), Italy; \\ katia.parati@istitutospallanzani.it \\ * Correspondence: dominic.ronga@gmail.com; Tel.: +39-0371-40471
}

Received: 20 March 2019; Accepted: 12 April 2019; Published: 15 April 2019

\begin{abstract}
Microalgae are attracting the interest of agrochemical industries and farmers, due to their biostimulant and biofertiliser properties. Microalgal biostimulants (MBS) and biofertilisers (MBF) might be used in crop production to increase agricultural sustainability. Biostimulants are products derived from organic material that, applied in small quantities, are able to stimulate the growth and development of several crops under both optimal and stressful conditions. Biofertilisers are products containing living microorganisms or natural substances that are able to improve chemical and biological soil properties, stimulating plant growth, and restoring soil fertility. This review is aimed at reporting developments in the processing of MBS and MBF, summarising the biologically-active compounds, and examining the researches supporting the use of MBS and MBF for managing productivity and abiotic stresses in crop productions. Microalgae are used in agriculture in different applications, such as amendment, foliar application, and seed priming. MBS and MBF might be applied as an alternative technique, or used in conjunction with synthetic fertilisers, crop protection products and plant growth regulators, generating multiple benefits, such as enhanced rooting, higher crop yields and quality and tolerance to drought and salt. Worldwide, MBS and MBF remain largely unexploited, such that this study highlights some of the current researches and future development priorities.
\end{abstract}

Keywords: microalgal extracts; crop nutrition; crop yield; crop quality; abiotic stresses; biostimulant; biofertiliser; crop protection products; sustainability

\section{Introduction}

Currently, considering the growing global population, among agricultural issues, a crucial challenge is to meet food demands, improving agricultural sustainability $[1,2]$. Hence, whilst farmers are called to increase agricultural production along with issues related to climate change, researchers must be called to develop innovative products and technologies able to increase crop yields and quality, while decreasing their agricultural carbon footprint [3-5].

Microalgae are classified mainly considering their pigmentation, life cycle and cell structure. It was estimated that $\sim 800,000$ microalgae species exist, of which $\sim 50,000$ species are described [6]. This high number of species might provide a wide range of possible uses. In fact, is possible to select different strains having different biochemical compositions and which are able to grow in different environments. Generally, biologists classify algae into four categories according to their sise 
and morphological characteristics [7]. This classification includes unicellular, colonial, filamentous, and multicellular algae.

Following this classification algae are divided into two main groups: Macro- and microalgae. Macroalgae are macroscopic organisms, multicellular, having a maximum length of $65 \mathrm{~m}$. On the other hand, microalgae are microscopic, unicellular or filamentous organisms, with small sise, from $\sim 1$ to $\sim 900 \mu \mathrm{m}[7,8]$.

Microalgae are photosynthetic organisms that can grow both in marine and freshwater environments [9]. Moreover, microalgae can be also produced using wastewater, allowing a reduction of the production costs [10]. The dominating species of microalgae available commercially are: Isochrysis spp., Chaetoceros spp., Chlorella spp., Arthrospira spp. and Dunaliella spp. [9]. Among them, Arthrospira spp. and Chlorella spp. are the main microalgae species cultivated and used commercially [11,12].

Microalgae are able to produce biomass that might be used in different sectors such as: Fuel, food, animal feed, pharmaceutical and crop productions [13]. Regarding crop productions, microalgae contain high levels of macronutrients and micronutrients essential for an optimal crop growth and development. Moreover, microalgae showed to have potential application as biostimulants and biofertilisers [14-17]. Nowadays, the use of microalgae in agriculture productions, especially as MBS or MBF, is attracting the interest of growers and agrochemical industries aiming to improve the sustainability of crop production [18,19].

Biostimulants and biofertilisers are considered environmentally friendly and cost-effective alternatives to synthetic products such as fertilisers, crop protection products and plant growth regulators [20]. Biostimulants are products that, when applied at low doses to seed, crop or soil, are able to regulate and enhance the crop's physiological processes [21]. Biostimulants act on the plant physiology through different pathways, improving crop growth, yields, quality, nutrient uptake, tolerance to abiotic stresses, and the shelf life of harvested products [22-24]. Biofertilisers are products containing living microorganisms or natural substances that are able to improve soil chemical and biological properties, stimulating plant growth, and restoring soil fertility [25].

Currently, the interest of biostimulants and biofertilisers in crop productions, and especially in the organic cropping system, is strongly increased [26]. Organic farming is generally characterised by lower crop yield compared to the conventional production systems. This yield gap is mainly ascribed to the different fertilisers and crop protection products that are allowed in the two cropping systems. In fact, synthetic and organic products can be used in the conventional and in the organic cropping systems, respectively [27-32]. In this context, the use of biostimulants and biofertilisers is attracting interest by growers [33]. These products might be very useful in improving agricultural sustainability; indeed they could facilitate high production with reduced environmental impact [34].

Several studies regarding MBS showed that these products are able to influence cellular respiration, photosynthesis, nucleic acid synthesis and ion uptake in plants [17,35-38]. Moreover, MBS can enhance soil nutrient availability for crop growth, improve soil water-holding capacity, increase the content of plant antioxidants, enhance cellular metabolism and increase leaf chlorophyll [17,21,39].

Until nowadays, microalgae were largely investigated as a practical approach for the production of lipids and for environmental purposes, such as the mitigation of carbon dioxide $\left(\mathrm{CO}_{2}\right)$ emitted by industrial processes, and for wastewater treatments [40]. On the other hand, investigations of microalgal products suitable for crop productions remain largely unexploited. In the light of this point, this study highlights some of the current researches and future development priorities, summarising the biological activity of microalgal components, and examining the factors supporting the use of MBS and MBF for managing crop productions and abiotic stresses.

\section{Microalgae Production}

Worldwide the most produced microalgae species are: Arthrospira spp., Chlorella spp., Dunaliella spp., Nostoc spp. and Aphanizomenon spp. [9]. 
The production of microalgae is a globally emerging activity due to its potential economic and commercial opportunities [41,42]. Microalgae can be produced using wastewater, recovering nutrients and preserving water for further use. In addition, microalgae can sequester $\mathrm{CO}_{2}$ and nitrous oxide $\left(\mathrm{N}_{2} \mathrm{O}\right)$ from industrial by-products, reducing greenhouse gas emissions [43].

Different systems for microalgal biomass production were proposed and used both for laboratories and industrial purposes [44,45]. Among them, raceway ponds are one of the most adopted systems in industrial processes. Raceway ponds are open systems having a depth between 10 and $50 \mathrm{~cm}$, to allow for appropriate illumination, and having a paddle wheel for gas/medium mixing and circulation. In this system, the growing medium is directly exposed to the air, allowing evaporation that regulates the temperature of the culture medium. This system is typically used for the production of microalgae and cyanobacteria, such as Arthrospira spp., Dunaliella spp., Anabaena spp., Phaeodactylum spp., Pleurochrysis spp., Chlorella spp. and Nannochloropsis spp. [46-54]. Another commonly used system is the photobioreactor, which is a closed system. Photobioreactors might be designed in different configurations, e.g., tubular or flat-plate reactors. They were used for the production of Porphyridium spp., Phaeodactylum spp., Arthrospira spp., Nannochloropsis spp., Chlorella spp., Haematococcus spp. and Tetraselmis spp. [55-64]. Typically, photobioreactors have higher volumetric productivity than open ponds, due to a better capture of the light, and a more optimal use of the cultivated area. On the other hand, raceway ponds can be made with less expensive materials, and they require less energy for mixing culture medium. Moreover, open ponds show a lower efficiency of radiant energy utilisation, lesser gas/liquid mass transfer, absence of temperature control, higher risk of contamination, and a lower productivity of microalgae compared to photobioreactors $[44,65,66]$. Both raceway ponds and photobioreactor systems are adopted in industrial processes to produce high quantities of biomass that might be used to obtain several products such as: Pigments, feed for animals, fatty acids and anti-oxidant compounds [67]. In the literature, information regards the average biomass productivity for conventional commercial-scale open ponds vs. photobioreactor systems reported data that are in the following ranges: For volumetric productivity $1.535 \mathrm{vs.} 0.117\left(\mathrm{~kg} \mathrm{~m}^{-3} \mathrm{~d}^{-1}\right)$; for square metre productivity 0.072 vs. $0.035\left(\mathrm{~kg} \mathrm{~m}^{-2} \mathrm{~d}^{-1}\right)$ and for biomass concentration in broth 4.00 vs. $0.14\left(\mathrm{~kg} \mathrm{~m}^{-3}\right)$, for open ponds and photobioreactors, respectively [68].

Nonetheless, microalgae productions showed a high cost of cultivation, and its utilisations should overcome several issues to become more economically viable [41,43,69-71] and environmentally sustainable $[41,72,73]$. The optimisation of culture medium was suggested as an important strategy for increasing the cost-effectiveness of microalgal productions [72]. The application of low-cost resources, such as nutrient-rich wastewaters, agricultural by-products and inexpensive fertilisers, are effective strategies for increasing the cost-effectiveness of microalgal productions [41,74]. Zhang et al. [75] proposed the co-production of microalga (Chlorella infusionum) and tomato (Solanum lycopersicum L.) using a hydroponic system. Microalgae usually grow spontaneously in hydroponics, but are considered a critical point, since they will cause some problems, such as nutritional competence and clogging of the pipelines. On the other hand, microalgae through the biochemical process of photosynthesis can supply oxygen $\left(\mathrm{O}_{2}\right)$ into the nutrient solutions useful for crop root respiration and growth. The same authors [75] showed that microalgae might be co-cultivated with tomato without requiring any additional inputs. A floating system was simulated, adopting a glass beaker of $22 \mathrm{~cm}$ height and $18 \mathrm{~cm}$ diameter, and the crop was fixed using $2 \mathrm{~cm}$ of polyethylene foam sheet and sponge strip. Light, water, and nutrients were sufficiently available for both microalgae and tomato productions; moreover, the symbiotic association between tomato root respiration and algal photosynthesis provide the $\mathrm{CO}_{2}$ and $\mathrm{O}_{2}$ which are fundamental for the optimum growth of microalgae and tomato, respectively. In fact, both the biomass productions of microalgae and tomato were enhanced. Thus, this simple system might be applied as a model for hydroponic co-productions of microalgae and crops [75].

Barone et al. [76] also suggested the co-production of tomato plants and microalgae (Scenedesmus quadricauda or Chlorella vulgaris). The experimental system consisted of a transparent container $(40 \times 20 \times 10 \mathrm{~cm})$, covered with a wire net used for crop fixation. S. quadricauda increased the shoot 
growth of tomato plants, along with an increase in microalgal biomass. Taking into account that hydroponic crop productions was increased in the world, the co-production of tomato and microalgae in the hydroponic system might be suggested as a new approach for a better, cheaper and eco-friendly productions of microalgae and tomato plants [76].

Several factors such as nutrients, light intensity, $\mathrm{pH}$ and electroconductivity (EC) might affect the growth and the chemical composition of the microalgae [77-80]. Moreover, the different characteristics of the growing medium, and in particular the source and the concentration of nitrogen $(\mathrm{N})$ can affect the growth and biochemical composition of microalgal species [80-83]. In fact, biomass productions of Arthrospira spp. are influenced by a variation of the $\mathrm{N}$ source $[77,78]$. On the other hand, the gross biochemical composition of the marine microalga Isochrysis spp. was affected more by the growth phase than by the N source [83].

Yang et al. [84] reported that potassium (K) is a very important element for microalgae growth. Arthrospira spp. has the ability to grow under extreme conditions of $\mathrm{pH}$ and salt concentration, showing an increase in biomass yields when sodium $(\mathrm{Na})$ was replaced by $\mathrm{K}$ in the medium at the same concentrations $(250 \mathrm{mM})$ [85]. On the contrary, Çelekli and Yavuzatmaca [86] showed that the highest biomass yield of Arthrospira spp. was observed at $1.5 \mathrm{~g} \mathrm{~L}^{-1}$ sodium chloride $(\mathrm{NaCl})$ and the same result was reported by Kemka et al. [79].

Some studies reported that biochemical stimulants such as phytohormones and polyamines might contribute to enhancing microalgae productivity $[87,88]$. Biochemical stimulants were screened for their influence on growth and chlorophyll concentration for the green alga Chlorella spp. Using natural and synthetic auxins, as well as their precursors, the growth of this microalga and its amount of proteins, saccharides and chlorophylls were significantly increased [89].

\section{Microalgal Extracts}

Microalgae biomass production can be used to obtain different kinds of extracts economically important in commerce. Generally, during the exponential growth phase, the maximum microalgal biomass yield is achieved. This biomass can be recovered from the broth by microfiltration or centrifugation [90]. One of the most common processes to preserve microalgal biomass is its pasteurisation, dehydration at $70{ }^{\circ} \mathrm{C}$ for $14 \mathrm{~h}$, and subsequent grinding and storage for further utilisations [91].

The microalgal active compounds are enclosed in the cell walls and/or linked to various structures [38]. For a high recovery of active compounds and their release from the cellular structures, microalgal biomass can be submitted to different processes, recently reviewed by Sharma et al. [92], including drying, cryo-processing (frozen biomass are treated by a mill which is cooled with liquid $\mathrm{N}$ to obtain a micronised suspension of fine particles) and cell rupture with high pressure treatments (biomass are treated with high pressure and are subsequently subject to a pressure reduction, causing the cell walls rupture, thus releasing their contents). Moreover, in microalgae, the high ratio of cell walls might require an enzymatic treatment (such as protease, cellulase, $\beta$-glucosidase, xylanase, $\beta$-glucanase, and pectinase) for an enhanced cell rupture [40,93,94].

Several extraction techniques can be used to extract microalgal compounds such as conventional liquid-liquid or solid-liquid extraction, pressurised-liquid extraction, subcritical and supercritical $\mathrm{CO}_{2}$ extractions, microwave, and ultrasound-assisted extractions [94-96]. One of the several systems used to obtain microalgal extracts is the adoption of a high-pressure piston homogeniser, with a knife edge valve. High pressure homogenisation causes disruption of the microalgal cells by lysis, induced by pressure variations, and a forced passing through the knife edge valve, with the separation of cell extracts and cell walls [40]. However, supercritical fluid extraction (pressure $\sim 500$ bar, temperature $\sim 50{ }^{\circ} \mathrm{C}$ and $\sim 100 \mathrm{~kg} \mathrm{CO} 2$ per $\mathrm{kg}$ of the load microalgal biomass) is attracting interest because the obtained microalgal extract is a concentration of biologically active compounds in a solvent-free environment [95]. 


\section{Chemical Compositions of Microalgal Biostimulants and Biofertilisers}

Different microalgae-based products (MBS and MBF) are available commercially for use in agriculture as innovative and promising products to improve crop yields [97]. The chemical characterises of the MBS and MBF are one of the most critical aspects of their use. In fact, both the different microalgal species and the industrial process used for the production of MBS and MBF might affect their final compositions. Typically, MBS and MBF labels report information regarding their composition, including the mineral element concentrations, the amino acids and phytohormone contents $[15,16]$. However, sometimes the concentration of most of the bioactive compounds is very low, and hence might be below the detection thresholds of the most innovative analytical instruments [26].

Microalgae biomass showed to contain micro- and macronutrients, especially N, phosphorous ( $\mathrm{P}$ ), and $\mathrm{K}$, and might be considered as an organic slow-release fertiliser [98]. Analysis of Arthrospira spp. dry biomass revealed that it contains $6.70,2.47$ and $1.14 \%$ on dry base of N, P and K, respectively [85], while, the calcium (Ca) content in the microalga is relatively lower than the other minerals [99]. In addition, some studies revealed that lead $(\mathrm{Pb})$ is totally absent in Arthrospira spp. biomass, which is a good indicator for the safe use of Arthrospira spp. as a plant growth promoter [85,100]. However, microalgae are also used in wastewater bioremediation due to their ability to concentrate heavy metals. The mechanisms (extracellular and intracellular) linked with metal absorption are complex, and influenced by microalgal species, metal ion $(\mathrm{Pb}>\operatorname{nickel}(\mathrm{Ni})>$ cadmium $(\mathrm{Cd})>$ zinc $(\mathrm{Zn}))$ and the growing system conditions (such as $\mathrm{pH}$ ) [101,102]. Mehta and Gaur [103] reported that complexation and microprecipitation are the most important mechanisms to avoid heavy metal toxicity used by microalgae. Hence, when microalgae are grown in wastewater, an accurate chemical analysis to detect the presence of heavy metal is fundamental in obtaining safe MBS and MBF.

Many studies indicated that microalgae contain some plant growth-promoting substances such as auxins, cytokinins, betaines, amino acids, vitamins and polyamines [104-108]. Stirk et al. [106] quantified auxin and cytokinin contents in 24 microalgae strains from the Chlorophyceae, Trebouxiophyceae, Ulvophyceae, and Charophyceae families. The general trend was that cis-zeatin was the predominant cytokinin. Moreover, microalgae can contain also important quantities of gibberellins and brassinosteroids [107].

Protein hydrolysates are also included among the active ingredients of plant biostimulants [18], and their use in a foliar spray application might enhance the biological activity in crops growth and development. Microalgae contains also amino acids that are a well-known biostimulant with positive effects on plant growth and crop yield. Moreover, amino acids can contribute to mitigate the injuries caused by abiotic stresses [109].

Finally, microalgae can contain polysaccharides (such as $\beta$-glucan) that are reported to be involved in the improvement of plant growth $[9,19]$. These compounds seem to interact with leucine-rich repeat membrane receptors that can activate mechanisms $[110,111]$ leading to the regulation of several genes involved in the cell expansion [112].

\section{Phytohormone-Like Activities}

Phytohormones, including auxins, cytokinins, abscisic acid, ethylene and gibberellins, were found in microalgal extracts, which are known to influence plant growth and development $[106,107,113]$. Microalgal extracts, containing phytohormones, might be a new prospect of phytohormone applications in crop productions, increasing opportunities of microalgae valorisation [114,115]. Phytohormones are small molecules that work as chemical messengers to regulate cellular activities in crops. Moreover, these compounds are able to influence metabolic processes, including photosynthesis, respiration, nucleic acid synthesis and nutrient uptake [116].

Both auxins and cytokinins are involved in several aspects of plant growth and development [117]. Auxins are involved in phototropism and gravitropism, root growth and development [117], cell division, elongation and turgor pressure [118]. Cytokinins are involved in root and shoot development, leaf senescence, nutrient mobilisation, breaking of bud dormancy, seed germination and they also play a fundamental role in cell division [119]. 
Abscisic acid regulates seed maturation and stress responses in plants [120]. Moreover, it was found to function as a stress molecule also in cyanobacteria [121]. High abscisic acid levels reduce ethylene synthesis that inhibits auxin transport and biosynthesis [122]. Abscisic acid and cytokinins are regulators of the cellular response to abiotic stresses. In microalgae, biosynthetic pathways of abscisic acid and cytokinins are up- and downregulated, respectively, upon an $\mathrm{N}$ deficiency [123].

Gibberellins regulate seed germination, stem elongation, leaf expansion and flower and seed development [124]. Gibberellins and auxins act synergistically, and gibberellins levels are positively regulated by auxins. On the other hand, there are antagonistic effects between gibberellins and abscisic acid levels, as well as between gibberellins and cytokinin levels $[125,126]$.

Brassinosteroids are recognised as a new class of compounds having a dual function, acting as growth-promoting hormones, and having a role in protecting against abiotic stresses [127]. Brassinosteroids have a synergistic effect with auxins, an additive effect with gibberellins and they also increase ethylene production [127].

In the literature, information regarding the application of microalgal phytohormones in crop productions is scarce, and only hypotheses on their activities are reported. One of the available studies was carried out by Plaza et al. [128], who assessed the phytohormone contents in Scenedesmus spp. and Arthrospira spp. Scenedesmus spp. had a higher concentration of cytokinins, gibberellins, auxins, salicylic acid, and abscisic acid compared to Arthrospira spp. Therefore, the authors suggested that Scenedesmus spp. extract might be used to increase plant growth and development, showing a great number of flowers, shoots, and leaves in petunias (Petunia $\times$ ibrida) [128].

Another study investigated the effects of Aulosira fertilissima on the growth of rice (Oryza sativa L.) [113]. The authors reported that the presence of root-promoting hormones (auxins, cytokinins and gibberellic acid) increased the growth of rice seedlings [113].

\section{Abiotic Stress Tolerance}

Crop production is often affected by several abiotic stresses. Nowadays, it is more difficult to reach the potential crop yields of cultivated plants due to the deficiency of irrigation water, salinisation of soils, low and high temperatures, all of which are some of the major agricultural constraints $[129,130]$.

Globally, 800 million hectares are affected by salinisation [131]. This issue is intensified by inappropriate chemical fertilisation managements that lead to osmotic imbalance in the nutrient solution, with subsequent damage to crop growth and fundamentally linked with a reduction of crop yields [132].

Biostimulants are products that might show positive effects on crop yield by reducing abiotic stresses and restoring damage already caused by unfavourable environmental conditions [18,133]. Regarding abiotic stresses, the efficacy of the biostimulants depend on the timing of application (before, during or after the stressful event). In addition the optimal dose is also an important factor, and in fact, different concentrations might positively or negatively influence crop growth [134].

The application of microalgal extracts might provide protection against abiotic stresses in plants [135]. Extracts from Dunaliella spp. and Phaeodactylum spp. mitigated salt stress during the seed germination process of bell pepper (Capsicum annuum L.) [136], due to a significant reduction in superoxide radical production, and in a low lipid peroxidation. El-Baky et al. [135] suggested that the application of microalgal extracts to wheat (Triticum aestivum L.) plants irrigated with seawater might be useful to improve wheat salinity tolerance. Water extract of microalgae Spirulina spp. and Chlorella spp. improved wheat tolerance to salinity, and enhanced the antioxidant capacity and protein content of the whole grains produced by treating plants with microalgal extracts [135].

MBS from Nannochloris spp. was tested on water-stressed and non-water-stressed tomato plants [40]. In non-water-stressed plants, the biostimulant determined a better development of root length, and an increased leaf number and leaf area compared to the control. Moreover, the application of MBS alleviated the effects of water stress on tomato plants, increasing plant height [40]. 


\section{Fertilisation}

Plant biostimulants are considered borderline products, showing intermediate effects between plant protection products and fertilisers. Currently, these products are regulated by national laws, and are differently named in the different European Member States [137], leading to unfair competition between stakeholders [138].

Fertilisation is one of the most common agricultural practices. In this regard, microalgae are considered as an organic fertiliser, having the potential to prevent nutrient losses through a gradual release of $\mathrm{N}, \mathrm{P}$, and $\mathrm{K}[98,139]$. Moreover, microalgae are able to recover $\mathrm{N}$ and $\mathrm{P}$ present in wastewaters by concentrating these nutrients in their biomass $[98,140]$.

In its commercial form, Arthrospira spp. contains different organic and inorganic compounds, suggesting that this microalga might be used as a biofertiliser [9].

Intensive crop productions may lead to nutrient depletion of the soil reservoir. In addition, unfavourable soil conditions, such as high or low $\mathrm{pH}$, salinity, calcium carbonate $\left(\mathrm{CaCO}_{3}\right)$ content [141-143] and the antagonism between macro- and micronutrients [144], can also affect the availability of some nutrients. Apart from macronutrients, micronutrients are also fundamental for the growth and development of all crops [145]. They are involved in the redox systems, and as co-enzymes for different processes in plant metabolisms $[146,147]$. Thus, micronutrient deficiency might cause severe problems in cell activities, which finally lead to non-optimal growth and less crop yield and quality $[142,148]$.

Some studies highlighted an association among greater nutrient uptake, higher biomass accumulation, and greater crop yields when microalgae are used as biofertilisers [15,16,149]. Different studies were performed to assess the effect of MBF on different crops such as rice, garlic (Allium sativum L.), fenugreek (Trigonella foenum-graecum L.) and tomato $[14,116,150,151]$, due to their potential possible applications in the different agricultural cropping systems, and to improve the agricultural sustainability.

An interesting study [152] assessed morphological and molecular responses induced by microalgal extracts of C. vulgaris and S. quadricauda in sugar beet (Beta vulgaris L. ssp. vulgaris) production. Seedlings of sugar beet were grown in Hoagland's solution under controlled conditions. After 5 days of growth, $2 \mathrm{~mL} \mathrm{~L}^{-1}$ and $4 \mathrm{~mL} \mathrm{~L}^{-1}$ of the two microalgal extracts were added to the nutrient solution. Afterwards, roots were sampled $36 \mathrm{~h}$ after the extract additions. The authors reported no significant changes in the ionic profile of the nutrient solutions treated with the two microalgal extracts with respect to the control. At the morphological level, the treated seedlings highlighted higher values of total root length, fine root length, and the number of root tips, than the untreated plants. At the molecular level, microalgal extracts upregulated some genes linked to different biological pathways and processes, including primary and secondary metabolisms and intracellular transports, especially involved in root traits related to nutrient acquisition [152].

\subsection{Soil Applications}

The beneficial characteristics of algal biomass as biofertilisers were already demonstrated for cyanobacteria and microalgae, due to the presence of bioactive growth-promoting compounds [153]. Although further researches are required to assess the optimal valorisation of microalgae used as biofertilisers, examples available from literature are reported here. Coppens and co-authors [98] recorded the increased sugar and carotenoid concentrations in tomato fruits treated with MBF (dry biomass of Nannochloropsis spp., Ulothrix spp. and Klebsormidium spp.), and showed the ability of these MBF to increase the quality and economic value of tomato fruits. Similar to tomatoes, MBF can enhance the quality of flowers (Rosa spp.), improving carotenoids that typically stimulate the yellow and orange colour of petals [154].

It is reported that combining and optimising the use of inorganic and organic fertilisers, together with the use of MBF, might make it possible to achieve a sustainable crop productivity $[98,155]$. Seeds of lettuce (Lactuca sativa L.) were germinated in soil containing different concentrations of MBF of 
C. vulgaris and grown for 3, 6, 9, 12 and 15 days in order to assess its effects on agronomic and physiological responses.

In general, microalgal treatment improved the seed growth with a significant enhancement of soluble carbohydrate, soluble protein and total free amino acids compared to the control. The application of microalgal biomass into the soil, improved the fresh and dry weight of seedlings as well as their pigment content. The best treatments were obtained using 2 and $3 \mathrm{~g}$ of dry microalgae per $\mathrm{kg}$ of soil [149].

Biofertiliser effects of the microalga Acutodesmus dimorphus (=Tetradesmus dimorphus) were assessed on tomato seedlings, and timing and dose of applied biofertiliser were investigated in relation to agronomic performances. Biofertilisers (50 and $100 \mathrm{~g}$ of dry biomass per $28-\mathrm{cm}$ pot) applied 22 days prior to seedling transplant increased plant growth, showing higher numbers of branches and flowers, compared both to the unfertilised control, and the application (of biofertiliser) at the time of transplant [14].

Coppens et al. [98] studied the $\mathrm{N}$ mineralisation rate of two different microalgal biomasses, that are microalgal bacterial flocs (Ulothrix spp. and Klebsormidium spp.) from a raceway pond, treating aquaculture wastewater, and a marine culture of Nannochloropsis spp. An initial $\mathrm{N}$ availability of 7 and $5 \%$ was reported for microalgal bacterial flocs and Nannochloropsis spp., respectively. The two microalgal biomasses were applied in the soil and after 21 days, 11 and $16 \%$ of the total $\mathrm{N}$ was mineralised, respectively. A final plant-available $\mathrm{N}$ fraction of 25 and $31 \%$ was highlighted after 95 days for the microalgal bacterial flocs and Nannochloropsis spp. biomass, respectively. The mineralisation rates were within the range displayed by commercially available slow-release fertilisers [156]. Although, the same authors reported that by using inorganic fertiliser, a faster initial plant growth was recorded, and ascribed to the readily-available inorganic nutrients [98,157], there were no significant differences in the final plant height, mean stem diameter, number of trusses and fruit for the inorganic fertiliser, organic fertiliser and MBF. On the other hand, leaf analysis showed higher N content for the MBF treatments compared to the control. The Nannochloropsis spp. treatment compared to the microalgal bacterial flocs treatment displayed lower Ca concentrations in the tomato leaves. In this regard, Ca deficiency is often linked to water stress [158], and therefore the Ca deficiency highlighted by this Nannochloropsis spp. treatment might be due to the high salt concentrations of the marine microalgal biomass [98]. The fresh weight of the full ripe tomatoes was higher using inorganic fertiliser, while no difference was observed between the organic fertiliser and MBF. The lower yields of the organic and Nannochloropsis spp. biofertilisers compared to the inorganic one, might be due to the high osmotic pressure caused by an increased salinity of both biofertilisers that reduced the water flux of the developing fruits. In fact, lower tomato yields were commonly recorded under salt stress conditions [159]. Also, differences in $\mathrm{N}$ availability among the assessed fertilisers can influence tomato fruit yield $[29,160]$.

Another important example of microalgae soil application is reported for rice, one of the oldest cultivated and most important staple crops. The soil inoculation with blue-green algae could be an alternative source of $\mathrm{N}$ to increase rice productivity [150]. A mixed inoculum of blue-green algae (Nostoc spp., Anabaena spp., Westiellopsis spp., Aulosira spp. and Scytonema spp.) was used (10 kg ha-1) in a field trial (using different levels of synthetic $\mathrm{N}$ ranged between 0 and $80 \mathrm{~kg}$ of N ha ${ }^{-1}$ ) compared to a single inoculum of Anabaena spp. [150]. In general, the results showed that plants inoculated with the mix inoculum increased grain yield up to $20.9 \%$ and straw yield up to $18.1 \%$, respectively.

Other studies observed improvement in rice seed germination, root and shoot growth, weight of rice grains and protein content using cyanobacteria (Nostoc spp., Hapalosiphon spp., and Aulosira fertilissima) as soil application $[161,162]$. These beneficial aspects were ascribed to the presence of root-promoting hormones such as auxins, cytokinins and gibberellic acid [113,161]. Karthikeyan et al. [162] clearly showed that cyanobacteria can excrete indoleacetic acid, amino acids and other growth promoting compounds, which in turn are able to stimulate both the growth of the soil microbial populations and crop development. 


\subsection{Foliar Applications}

Microalgae allow an efficient recovery of the micronutrients present in growing medium by concentrating these nutrients in microalgal biomass [163]. Micronutrients applied to the soil may not meet the crop requirements due to physical and chemical problems of the soil. Hence, foliar spray fertilisation is an alternative available technique for satisfying the crop nutrient request essential to achieve high yield productions [164]. Recently, foliar spray application of biochemical organic substances, that can supply both macro and micronutrients, is one of the most innovative agricultural practices, as they have the advantage that they are safe to the environment, increasing the agricultural sustainability $[15,16]$. Microalgal extracts can partially replace micronutrient foliar fertilisers acting complementary with $\mathrm{N}$, improving in turn the nutrient uptake. Microalgal extracts, when applied as foliar spray, showed an increased $\mathrm{N}$-content in root and shoot tissues [165]. This can be explained by the improvement in nutrient uptake and by a regulation of physiological plant mechanisms [16].

Battacharyya et al. [166] reported that nutrients available in the microalgal extracts are readily absorbed by the leaf through its stomata and cuticle pores, showing the best effectiveness if applied in the morning, when stomata pores are completely open.

Some studies found a positive effect of microalgae fertilisers, especially when applied to the leaves of horticultural and ornamental crops such as aubergine (Solanum melongena L.), garlic, pepper, tomato and petunia $[3,14,40,85,128,151]$. Plant responses to nutrients supplied via foliar sprays are normally more rapid than when applied as a soil amendment [167]. Such nutrients are available in a reasonable percentage in microalgae extracts, especially P [15], $\mathrm{K}$, iron (Fe), magnesium $(\mathrm{Mg})$, and $\mathrm{Ca}$ [9]. Moreover, microalgal extracts can contain phytohormones, enzymes and vitamins that may improve nutrient assimilation and solute translocation, leading to significant increases in crop yield [15,16].

In this regard, Tarraf et al. [116] showed that fenugreek plants treated with microalgae extract of Arthrospira spp. showed higher N, P, and K contents, especially at $5 \mathrm{~g} \mathrm{~L}^{-1}$ compared to the untreated plants. However, Dias et al. [3] found that foliar application of Arthrospira spp. at low concentrations $\left(10 \mathrm{~g} \mathrm{~L}^{-1}\right)$ did not affect the leaf content of $\mathrm{N}, \mathrm{P}, \mathrm{K}$, and $\mathrm{Na}$ in aubergine. In the study conducted by Dias et al. [3], the growth, yield, and postharvest quality of aubergine grown under different foliar fertiliser treatments with Spirufert ${ }^{\circledR}$ (Tamanduá, Brasil) containing Arthrospira spp., were also investigated. Spirufert ${ }^{\circledR}$ applied at low concentrations $\left(10 \mathrm{~g} \mathrm{~L}^{-1}\right)$ resulted in greater fruit yield. On the other hand, using high concentrations of the extract $\left(45 \mathrm{~g} \mathrm{~L}^{-1}\right)$ an increased vegetative growth was observed, but the reduced aubergine yield was recorded. Fruit colour parameters and soluble solids contents were not affected by fertiliser application, apart from pulp firmness that recorded high values using a concentration of $10 \mathrm{~g} \mathrm{~L}^{-1}$.

A field experiment using pepper plants was carried out on sandy soil for evaluation of Arthrospira spp. biostimulator as a foliar application, at the rate of $80 \mathrm{~g} \mathrm{~L}^{-1}$ applied every 15 days, in comparison with compost and the optimal dose of NPK. It could be concluded that the yield of pepper treated with biostimulant was improved compared to organic fertiliser containing NPK [85].

Michalak et al. [95] reported no phytotoxic symptoms on winter wheat treated with Arthrospira spp. extract obtained using supercritical extraction, compared to the reference product containing Ascophyllum nodosum marine algae (Forthial, Goëmar, France). Plant vigour, crop height, ear length, shank length and yield were similar in all the treated and the untreated plants. A high number of grains in the ear were assessed on the plants treated with Arthrospira spp. extract at the dose of $1.5 \mathrm{~L} \mathrm{ha}^{-1}$. No lodging of plants was recorded in all the plots. The results of this study displayed that the formulations containing supercritical algal extracts performed similar to any biostimulant available commercially [95].

The effects of green alga $C$. vulgaris cell extract as a foliar fertiliser on nutrient status, the growth and yield of wheat plants, were studied and compared to a commercial synthetic micronutrient foliar fertiliser [16]. The application of $50 \% v / v$ of microalgal extract was the best treatment in terms of fresh weight $(+60.7 \%)$, yield $(+140 \%)$ and grain weight $(+40 \%)$ compared to the control. On the other hand, 
applying $100 \%$ microalgal extract was the best treatment in terms of dry weight $(+95 \%)$, spike weight $(+60 \%)$ and 100 grains weight $(+160 \%)$ compared to the control [16].

Oliveira et al. [168] assessed the production of red beet (Beta vulgaris L.), in an organic cropping system, assessing biostimulant containing the extract of microalgae Arthrospira spp. The treatments consisted of foliar spray application at two concentrations $\left(1.5 \mathrm{~g} \mathrm{~L}^{-1}\right.$ and $\left.3.0 \mathrm{~g} \mathrm{~L}^{-1}\right)$ of biostimulant and a control. Applications were performed every two weeks recording the following traits (at harvesting time): Fresh weight, dry weight and the diameter of the hypocotyl. The application of biostimulant containing Arthrospira spp. resulted in higher dry and fresh weights compared to the control [168].

Regarding ornamental plants, foliar spray applications using Arthrospira spp. and Scenedesmus almeriensis extracts at the concentration of $10 \mathrm{~g} \mathrm{~L}^{-1}$ were assessed in petunia production. Foliar sprayings were applied five times $(0,14,28,35$, and 42 days after transplanting). The results of this assay showed that a foliar application of $S$. almeriensis extract improved plant development in terms of higher rates of root, leaf and shoot growth, and earliness of flowering compared to the control. On the other hand, Arthrospira spp. extract improved the root dry matter, the number of flowers per plant, and the plant water content. In general, these results suggested that the use S. almeriensis extract as a foliar spray application can increase the blooming of petunia [126].

Microalgal extract of Acutodesmus dimorphus (=Tetradesmus dimorphus) used as a foliar spray application at $3.75 \mathrm{~g} \mathrm{~L}^{-1}$ showed an increased tomato plant growth. In particular, a high plant height and a great number of flowers and branches per plant were recorded when tomato plants were sprayed with extract of $A$. dimorphus (=T. dimorphus) [14]. In the same study, the authors investigated the use of $A$. dimorphus ( $=T$. dimorphus) extract as seed primer, showing that using extract concentrations at $0.75 \mathrm{~g} \mathrm{~mL}^{-1}$ seed germination was triggered faster, 2 days earlier than the control [14].

Field experiments were carried out to assess the influence of Arthrospira fusiformis (=Limnospira fusiformis) extract (at a rate of $1 \mathrm{~mL} \mathrm{~L}^{-1}$ ) on plant growth, yield, yield components and shelf life of garlic plants. One month after planting, biostimulants were applied as foliar spray, and repeated 3 times at 15-day intervals throughout the growing season. Results indicated that foliar spray applications only increased plant height, compared to the control [151].

Elarroussia et al. [19] investigated the possible use of microalgae extracts containing polysaccharides, as biostimulant for plant growth. Polysaccharides extracted from Arthrospira spp. were applied as a foliar spray on tomato and pepper plants at different growth stages. The treatment with a concentration of $3 \mathrm{~g} \mathrm{~L}^{-1}$ improved the plant sise of tomato and pepper by 20 and 30\%, respectively. The effects of treatments on root weight were more marked in tomato $(+230 \%)$ than pepper plants $(+67 \%)$. Moreover, the sise and number of nodes per plant were also improved after the treatment by $57 \%$ and $100 \%$ and $33 \%$ and $50 \%$ in tomato and pepper, respectively.

\section{Economic Assessment of Microalgal Extracts}

Coppens et al. [98] reported an interesting economic assessment of an outdoor raceway pond for microalgae production. The microalgal production cost was estimated at $23 €$ per kg of biomass produced, corresponding to $289 €$ per $\mathrm{kg}$ of N. Commercial inorganic NPK fertilisers (having $14 \% \mathrm{~N}$, $7 \% \mathrm{P}, 15 \% \mathrm{~K}$ ) and organic slow-release fertilisers (having $4 \% \mathrm{~N}, 2 \% \mathrm{P}, 5 \% \mathrm{~K}$ ) displayed a market value of $7.9 €$ and $11 €$ per $\mathrm{kg}$ of $\mathrm{N}$, respectively. This data indicates that the use of microalgal biomass as biofertiliser is not economically competitive, compared to the commercial fertilisers when administered as a source of $\mathrm{N}$ fertiliser for plant growth. However, this economic assessment did not take into account the additional savings benefits that can be obtained using microalgae. For instance, the production of microalgae using wastewater permits the concentration of excess nutrients in microalgal biomass, thus reducing its release into the environment, and permitting the reclamation of water for extra use. Moreover, the valorisation of unused greenhouse space for indoor microalgae production might decrease their cost of production through the already presence of artificial lighting and heating [98]. In turn, the recycling of greenhouse wastewaters for microalgae productions may reduce the dependence of inorganic fertilisers and generate incomes from hydroponic co-productions $[75,76]$. Additionally, 
the plant growth-promoting compound present inside the microalgal biomass demonstrated that the nutrient concentration through microalgae production give an added value vs. the direct use of wastewater on soil [139].

Finally, the production of microalgal biomass from wastewater can valorise waste nutrients into sustainable and innovative biofertilisers with commercial opportunity in crop productions [98].

\section{A Case Study: Effects of Microalgal Extracts on Seed Germination and Antimicrobial Bioassay}

To investigate the biological effects of some selected microalgae cultivated in our Institute under controlled conditions, their extracts were prepared and tested to assess seed germination on cress (Lepidium sativum L.) and for their antimicrobial potential on selected strains of Gram-negative and Gram-positive bacteria.

\subsection{Materials and Methods}

The microalgal strains used in the present study were: Arthrospira platensis, Chlorella vulgaris, Isochrysis galbana, Nannochloropsis gaditana (=Microchloropsis gaditana), Porphyridium cruentum (=P. purpureum), Scenedesmus acuminatus (=Tetradesmus lagerheimii) and Tetraselmis suecica, isolated from the water of a pond in Pianura Padana (Italy) and from the coastal waters of the North Italy Sea. The unialgal culture of each strain was maintained under photoautotrophic conditions, in a $500 \mathrm{~mL}$ sterilised Erlenmeyer flask containing $250 \mathrm{~mL}$ of standard medium, at $22 \pm 1{ }^{\circ} \mathrm{C}$ on a rotary shaker at $100 \mathrm{rpm}$ and photoperiod of 12:12 h light and dark periods, using $40 \mathrm{~W}$ cool white fluorescent tubes $20 \mu \mathrm{mol}$ photons $\mathrm{m}^{-2} \mathrm{~s}^{-1}$. Standard media used in the present study were different, depending on the microalgae strain: Zarrouk medium [169], $\mathrm{pH}$ (9.5) was used for A. platensis; MBBM medium (Sigma-Aldrich), $\mathrm{pH}$ (7.0) was used for C. vulgaris and S. acuminatus (=T. lagerheimii); Guillard (F/2) medium [170], with $\mathrm{NaNO}_{3}(2 \mathrm{mM}), \mathrm{NaH}_{2} \mathrm{PO}_{4}(100 \mu \mathrm{M}), \mathrm{ZnCl}_{2}(1 \mu \mathrm{M}), \mathrm{MnCl}_{2}(1 \mu \mathrm{M}), \mathrm{Na}_{2} \mathrm{MoO}_{4}$ $(1 \mu \mathrm{M}), \mathrm{CoCl}_{2}(0.1 \mu \mathrm{M}), \mathrm{CuSO}_{4}(0.1 \mu \mathrm{M})$, ferric citrate $(20 \mu \mathrm{M})$, thiamine $\left(35 \mathrm{pg} \mathrm{L}^{-1}\right)$, biotin $\left(5 \mathrm{pg} \mathrm{L}^{-1}\right)$, B12 (3 pg L $\left.{ }^{-1}\right)$, EDTA $(26.4 \mu \mathrm{M})$, TRIS-HCL $(15 \mathrm{mM}), \mathrm{pH}(7.6)$ for I. galbana, N. gaditana (=M. gaditana), P. cruentum (=P. purpureum) and T. suecica.

A lab-scale 5 L-balls culture was assessed for each strain, and used as the inoculum $(10 \% v / v)$ for the pilot scale production in the vertical-column photobioreactors (PBRs). The PBRs were made of semirigid plastic, with working volume of 200 L (Figure 1).

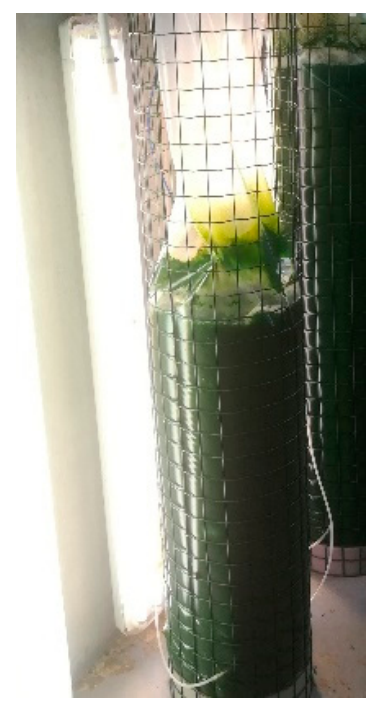

Figure 1. Vertical-column photobioreactor used for the production of microalgae.

Mixing energy was provided by a gas intake (mix half of air and $\mathrm{CO}_{2}$ ), thus combining aeration and dispersion. The reaction volume was sparged by using an air injection device, connected to a 
plastic pipe, connected to porous stones placed at the base of cylindrical photobioreactors, which releases the air bubbles from the bottom.

The PBRs were located indoor, and the cultures were illuminated by using cool white fluorescent lamps $\left(20 \mu \mathrm{mol}\right.$ photons $\left.\mathrm{m}^{-2} \mathrm{~s}^{-1}\right)$. The resulting suspension was harvested during the exponential growth phase by centrifugation at $3000 \times g$, in continuous mode, using a US FILTERMAXX, 10.000G instrument and lyophilised by Alpha 1-4 LSC Christ instrument, at a shelf temperature of $-20^{\circ} \mathrm{C}$ at a pressure of $0.320 \mathrm{mbar}$. After $48 \mathrm{~h}$ of treatment the samples were vacuum-sealed.

\subsection{Seed Germination}

The influence of different microalgal extracts on cress germination was assessed by a phytotoxicity test that was performed following Zucconi et al. [171]. Briefly, $4 \mathrm{~mL}$ of each microalgal extract (50 $\mathrm{mg}$ of dry biomass in $1 \mathrm{~L}$ of distillate water), plus a control 138 treatment of only water were added to Petri dishes containing Whatman filter paper. The $\mathrm{pH}$ and $\mathrm{EC}$ of the extracts were determined using a CRISON pH meter basic 20, and CRISON GLP 31 EC meter, respectively. Three replicates of 15 seeds were prepared, and the plates (Figure 2) were incubated for $36 \mathrm{~h}$ at $25^{\circ} \mathrm{C}$ in a Binder ED53, Tuttlingen (Germany) heating chamber.

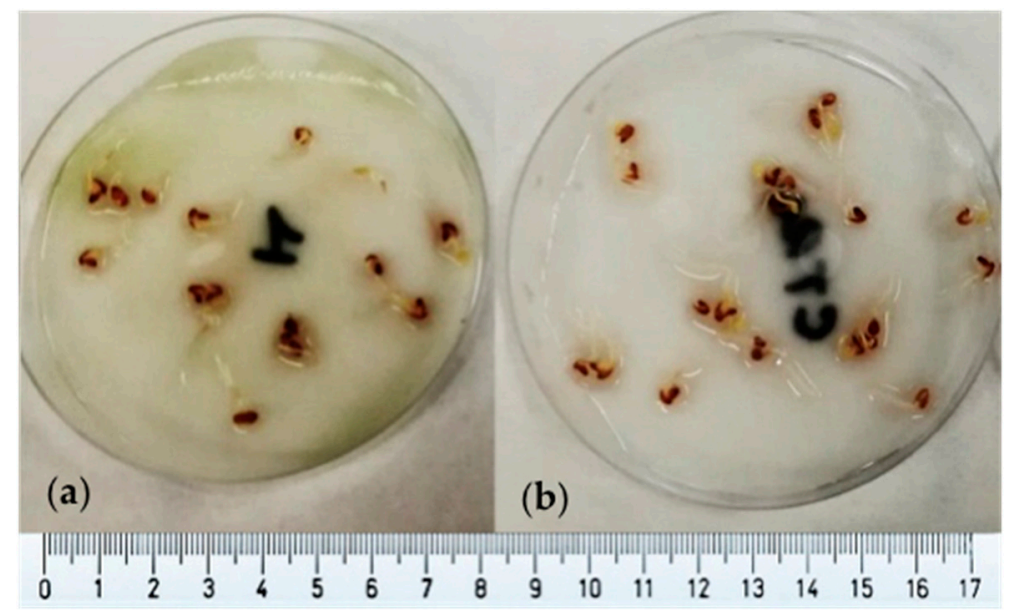

Figure 2. Germinated seeds using A. platensis extracts (a) vs. water (b) used as a control.

The number of germinated seeds and the average length of roots were recorded in order to calculate a Germination Index (GI\%) according to the following formula [172]:

$$
\mathrm{GI} \%=100 \times(\mathrm{Gt} / \mathrm{Gc}) \times(\mathrm{Rt} / \mathrm{Rc})
$$

where, Gt is the number of germinated seeds of the treatment; Gc is the number of germinated seeds of the control; Rt is the average length $(\mathrm{mm}$ ) of the roots of the treatment and Rc is the average length $(\mathrm{mm})$ of the roots of the control.

The recorded data were analysed by Analysis of Variance (ANOVA), using GenStat 17th edition software. Differences between the means were analysed using the Duncan test at $p<0.05$. The results of the germination assay (Table 1) demonstrate that no microalgal extracts displayed phytotoxicity problems (values greater than 50\%), as reported by Zucconi et al. [171]. In particular, for cress, the value of A. platensis was the highest, while S. acuminatus (=T. lagerheimii) and T. suecica reported the lowest values compared to other treatments. 
Table 1. Microalgal extracts assessment on cress germination.

\begin{tabular}{|c|c|c|c|}
\hline Microalgae & $\mathrm{pH}$ & $\mathrm{EC}\left(\mathrm{ds} \mathrm{\textrm {m } ^ { - 1 } )}\right.$ & GI (\%) \\
\hline A. platensis & $8.00 \pm 0.18$ & $0.01 \pm 0.02$ & $152.99 \pm 2.00 \mathrm{a}$ \\
\hline C. vulgaris & $8.10 \pm 0.03$ & $0.01 \pm 0.02$ & $144.51 \pm 10.05 \mathrm{ab}$ \\
\hline I. galbana & $8.10 \pm 0.04$ & $0.02 \pm 0.00$ & $133.72 \pm 2.11 \mathrm{~b}$ \\
\hline N. gaditana $(=M$. gaditana $)$ & $8.10 \pm 0.06$ & $0.01 \pm 0.02$ & $142.58 \pm 9.98 \mathrm{ab}$ \\
\hline P. cruentum (=P. purpureum) & $7.90 \pm 0.46$ & $0.04 \pm 0.00$ & $147.98 \pm 3.00 \mathrm{ab}$ \\
\hline S. acuminatus (=T. lagerheimii) & $8.20 \pm 0.05$ & $0.00 \pm 0.00$ & $97.30 \pm 7.2 c$ \\
\hline T. suecica & $8.10 \pm 0.05$ & $0.01 \pm 0.02$ & $90.56 \pm 13.32 \mathrm{c}$ \\
\hline
\end{tabular}

Mean values followed by different letters $(\mathrm{a}, \mathrm{b}$ or $\mathrm{c}$ ) are different at $p<0.05$ according to analysis of variance; \pm , standard deviation.

\subsection{Antimicrobial Bioassay}

The microbiological quality of the harvested crop is an important parameter to keep under control. Thus, the seven microalgae tested in the case study were treated with different solvents with increasing polarity, hexane (non-polar), ethyl acetate:chloroform 1:1 (medium polarity), water:methanol 7:3 (polar), to obtain the corresponding extracts, that were dried, suspended in dimethyl sulfoxide (DMSO), and used for evaluation of antimicrobial activity.

Six bacterial strains were examined, namely Staphylococcus aureus ATCC12600, Enterococcus faecium ATCC19433, and Listeria innocua LIN11 (CREA collection) as Gram-positive bacteria, Escherichia coli ATCC11775, Pseudomonas fluorescens ATCC13525, and Salmonella spp. SAN39 (CREA collection) as Gram-negative bacteria. Bacterial strains were cultivated in Tryptone Soya Broth (TSB, Thermo Scientific Oxoid, Basingstoke, UK) at $37^{\circ} \mathrm{C}$ for $18 \mathrm{~h}$. The antimicrobial tests were performed in vitro by the agar disc diffusion technique [173]. Each bacterial culture was diluted and inoculated in melted $\left(45^{\circ} \mathrm{C}\right)$ Tryptone Soya Agar (TSA, Oxoid) to obtain a final concentration of $10^{6} \mathrm{CFU} \mathrm{mL}$. Volumes of $15 \mathrm{~mL}$ were distributed in sterile plates, and allowed to solidify. Sterile paper discs $(6 \mathrm{~mm}$ diameter) were impregnated with $15 \mu \mathrm{L}$ of different microalgal extracts and placed on the agar surface. As negative controls, discs were impregnated with $15 \mu \mathrm{L}$ of DMSO. As positive controls, $15 \mu \mathrm{L}$ of sterile solutions of ampicillin (128 $\mathrm{mg} \mathrm{L}^{-1}$, for Gram-positive bacteria) and gentamicin (128 $\mathrm{mg} \mathrm{L}^{-1}$, for Gram negative bacteria) were used. The plates were incubated at $37^{\circ} \mathrm{C}$ for $24 \mathrm{~h}$. The inhibition zones around the discs were visually examined, and the diameter $(\mathrm{mm})$ measured. All the assays were carried out in duplicate.

The three different solvents used had different yields, both depending on the type of solvent and the microalgae species. Therefore, the extracts suspended in DMSO had different final concentrations $(w / v)$ ranging between 10 and $100 \mathrm{mg} \mathrm{mL}^{-1}$ (Table S1). The antibacterial activity of microalgae extracts against selected bacteria varied, depending on the species and the polarity of the solvents used for extraction. The DMSO used as a solvent of dried extracts did not demonstrate antimicrobial activity itself.

All the 21 extracts did not show inhibitory activity against the Gram-negative strains. Three non-polar extracts (i.e., from C. vulgaris, I. galbana and $N$. gaditana $(=M$. gaditana)) were active against the Gram-positive bacteria E. faecium ATCC 19433 and S. aureus ATCC 12600. Among other extracts, only the medium polarity extract from I. galbana was active against E. faecium. A lower antibacterial activity of polar extracts was described. Water supernatant and methanolic extracts were less active against Gram-positive than Gram-negative bacteria, because of the more complex cell wall structure of Gram-negative bacteria that prevents the active compound to penetrate $[174,175]$. However, many different results in the determination of antimicrobial activity can be found in the literature consequent to the different strains used, different methods of extraction applied, and different ranges of microalga material concentration used in the assays [176]. 


\section{Conclusions and Future Directions}

Microalgae extracts received a greater interest in crop productions as MBS and MBF. Different formulations are now available commercially, and a growing number of the agrochemical companies are including microalgal extracts in the formulations of innovative MBS and MBF. In particular, microalgal extracts showed a number of beneficial effects, such as increased nutrient uptake, induced tolerance to abiotic stresses, and improved crop yield and quality. However, there are a several points that still need to be addressed to better understand how and when microalgal extracts might be used in crop productions to improve the agricultural sustainability. In fact, some of the following points required more investigations, both in term of microalgae productions and microalgal extract preparations and applications:

1. Several microalgae strains exist, and therefore different MBS and MBF can be proposed;

2. during the microalgae production several abiotic factors can influence the biochemical composition of microalgae;

3. even if the same microalga is processed, by using different extraction methods, several MBS and MBF might be obtained, showing different biochemical composition and characteristics;

4. the bioactive compounds contained in the MBS and MBF might activate different physiological pathways at different concentrations;

5. the crop phenological stage may influence the timing of MBS and MBF applications;

6. the frequency of the applications of MBS and MBF and the amount that should be applied;

7. the days that the effect persists after the application of MBS and MBF;

8. different crop species can respond differently to the same MBS and MBF;

9. different cultivars can show different sensitivity thresholds to the same MBS and MBF.

All of the listed critical points suggest a more and accurate assessment of the production and the application of several MBS and MBF nowadays available.

Agronomic, physiological, chemical, biochemical, and molecular studies are required to better understand the changes induced by the MBS and MBF in crop productions. This would permit a detailed collection of information regarding the best preparation and use of MBS and MBF. All this information might allow the definition of precise protocols that can help agrochemical industries and farmers in the production and in the applications of MBS and MBF, respectively.

Supplementary Materials: The following are available online at http://www.mdpi.com/2073-4395/9/4/192/s1, Table S1: Antibacterial activity of Microalgae extracts obtained by different solvents.

Author Contributions: D.R. prepared the manuscript. D.R., E.B., K.P., D.C. and E.C. conducted the experiments. A.T. designed the study. All authors have read and approved the final manuscript.

Funding: This research was funded by Fondazione Cariplo, Milano, Italy, grant No. 2015/1411 “Il Polo delle Microalghe. Le Microalghe per il trattamento e la valorizzazione di rifiuti e sottoprodotti agro-zootecnici e caseari $(\mathrm{MiReAZoC})^{\prime \prime}$.

Acknowledgments: Technical support from Agata Ursino and Barbara Pintus of CREA-ZA Lodi, is gratefully acknowledged.

Conflicts of Interest: The authors declare no conflict of interest.

\section{References}

1. Godfray, H.C.J.; Beddington, J.R.; Crute, I.R.; Haddad, L.; Lawrence, D.; Muir, J.F.; Pretty, J.; Robinson, S.; Thomas, S.M.; Toulmin, C. Food security: The challenge of feeding 9 billion people. Science 2010, 327, 812-818. [CrossRef]

2. Odegard, I.Y.R.; Van der Voet, E. The future of food-Scenarios and the effect on natural resource use in agriculture in 2050. Ecol. Econ. 2014, 97, 51-59. [CrossRef] 
3. Dias, G.A.; Rocha, R.H.C.; Araújo, J.L.; De Lima, J.F.; Guedes, W.A. Growth, yield, and postharvest quality in eggplant produced under different foliar fertiliser (Spirulina platensis) treatments. Semin. Cienc. Agrar. 2016, 37, 3893-3902. [CrossRef]

4. Foley, J.A.; Ramankutty, N.; Brauman, K.A.; Cassidy, E.S.; Gerber, J.S.; Johnston, M.; Mueller, N.D.; O'Connell, C.; Ray, D.K.; West, P.C.; et al. Solutions for a cultivated planet. Nature 2011, 478, 337. [CrossRef]

5. Tilman, D.; Cassman, K.G.; Matson, P.A.; Naylor, R.; Polasky, S. Agricultural sustainability and intensive production practices. Nature 2002, 418, 671. [CrossRef]

6. Suganya, T.; Varman, M.; Masjuki, H.H.; Renganathan, S. Macroalgae and microalgae as a potential source for commercial applications along with biofuels production: A biorefinery approach. Renew. Sustain. Energy Rev. 2016, 55, 909-941. [CrossRef]

7. Nabti, E.; Jha, B.; Hartmann, A. Impact of seaweeds on agricultural crop production as biofertiliser. Int. J. Environ. Sci. Technol. 2017, 14, 1119-1134. [CrossRef]

8. Kurniawati, H.A.; Ismadji, S.; Liu, J.C. Microalgae harvesting by flotation using natural saponin and chitosan. Bioresour. Technol. 2014, 166, 429-434. [CrossRef] [PubMed]

9. Priyadarshani, I.; Rath, B. Commercial and industrial applications of micro algae-A review. J. Algal Biomass Utln. 2012, 3, 89-100.

10. Acien, F.G.; Gómez-Serrano, C.; Morales-Amaral, M.M.; Fernández-Sevilla, J.M.; Molina-Grima, E. Wastewater treatment using microalgae: How realistic a contribution might it be to significant urban wastewater treatment? Appl. Microbiol. Biotechnol. 2016, 100, 9013-9022. [CrossRef]

11. Schmitz, R.; Magro, C.D.; Colla, L.M. Aplicações ambientais de microalgas. Rev. CIATEC-UPF 2012, 4, 48-60. [CrossRef]

12. Görs, M.; Schumann, R.; Hepperle, D.; Karsten, U. Quality analysis of commercial Chlorella products used as dietary supplement in human nutrition. J. Appl. Phycol. 2010, 22, 265-276. [CrossRef]

13. Metting, B.; Zimmerman, W.J.; Crouch, I.J.; van Staden, J. Agronomic uses of seaweed and microalgae. In Introduction to Applied Phycology, 1st ed.; SPB Academic Publishing: The Hague, The Netherlands, 1990; pp. 269-627.

14. Garcia-Gonzalez, J.; Sommerfeld, M. Biofertiliser and biostimulant properties of the microalga Acutodesmus dimorphus. J. Appl. Phycol. 2016, 28, 1051-1061. [CrossRef] [PubMed]

15. Shaaban, M.M. Nutritional status and growth of maise plants as affected by green microalgae as soil additives. J. Biol. Sci. 2001, 6, 475-479.

16. Shaaban, M.M. Green microalgae water extract as foliar feeding to wheat plants. Pak. J. Biol. Sci. 2001, 4, 628-632.

17. Khan, S.A.; Hussain, M.Z.; Prasad, S.; Banerjee, U.C. Prospects of biodiesel production from microalgae in India. Renew. Sustain. Energy Rev. 2009, 13, 2361-2372. [CrossRef]

18. Calvo, P.; Nelson, L.; Kloepper, J.W. Agricultural uses of plant biostimulants. Plant Soil 2014, 383, 3-41. [CrossRef]

19. Elarroussia, H.; Elmernissia, N.; Benhimaa, R.; El Kadmiria, I.M.; Bendaou, N.; Smouni, A.; Wahbya, I. Microalgae polysaccharides a promising plant growth biostimulant. J. Algal Biomass Utln. 2016, 7, 55-63.

20. Kawalekar, J.S. Role of biofertilisers and biopesticides for sustainable agriculture. J. Biol. Innov. 2013, 2, 73-78.

21. Zhang, X.; Schmidt, R.E. The impact of growth regulators on the $\alpha$-tocopherol status in water-stressed Poa pratensis. Int. Turfgrass Soc. Res. J. 1997, 8, 1364-2137.

22. Du Jardin, P. Plant biostimulants: Definition, concept, main categories and regulation. Sci. Hortic. 2015, 196, 3-14. [CrossRef]

23. Rouphael, Y.; Colla, G. Synergistic biostimulatory action: Designing the next generation of plant biostimulants for sustainable agriculture. Front. Plant Sci. 2018, 9, 1655. [CrossRef]

24. Yakhin, O.I.; Lubyanov, A.A.; Yakhin, I.A.; Brown, P.H. Biostimulants in plant science: A global perspective. Front. Plant Sci. 2017, 7, 2049. [CrossRef]

25. Abdel-Raouf, N.; Al-Homaidan, A.A.; Ibraheem, I.B.M. Microalgae and wastewater treatment. Saudi J. Biol. Sci. 2012, 19, 257-275. [CrossRef]

26. Toscano, S.; Romano, D.; Massa, D.; Bulgari, R.; Franzoni, G.; Ferrante, A. Biostimulant applications in low input horticultural cultivation systems. Italus Hortus 2018, 25, 27-36.

27. De Ponti, T.; Rijk, B.; Van Ittersum, M.K. The crop yield gap between organic and conventional agriculture. Agric. Syst. 2012, 108, 1-9. [CrossRef] 
28. Orsini, F.; Maggio, A.; Rouphael, Y.; De Pascale, S. "Physiological quality” of organically grown vegetables. Sci. Hortic. 2016, 208, 131-139. [CrossRef]

29. Ronga, D.; Lovelli, S.; Zaccardelli, M.; Perrone, D.; Ulrici, A.; Francia, E.; Milc, J.; Pecchioni, N. Physiological responses of processing tomato in organic and conventional Mediterranean cropping systems. Sci. Hortic. 2015, 190, 161-172. [CrossRef]

30. Ronga, D.; Zaccardelli, M.; Lovelli, S.; Perrone, D.; Francia, E.; Milc, J.; Ulrici, A.; Pecchioni, N. Biomass production and dry matter partitioning of processing tomato under organic vs. conventional cropping systems in a Mediterranean environment. Sci. Hortic. 2017, 224, 163-170. [CrossRef]

31. Ronga, D.; Caradonia, F.; Setti, L.; Hagassou, D.; Giaretta Azevedo, C.V.; Milc, J.; Pedrazzi, S.; Allesina, G.; Arru, L.; Francia, E. Effects of innovative biofertilisers on yield of processing tomato cultivated in organic cropping systems in northern Italy. Acta Hortic. 2019, 1233, 129-136. [CrossRef]

32. Ronga, D.; Gallingani, T.; Zaccardelli, M.; Perrone, D.; Francia, E.; Milc, J.; Pecchioni, N. Carbon footprint and energetic analysis of tomato production in the organic vs. the conventional cropping systems in Southern Italy. J. Clean. Prod. 2019, 220, 836-845. [CrossRef]

33. Bulgari, R.; Cocetta, G.; Trivellini, A.; Vernieri, P.; Ferrante, A. Biostimulants and crop responses: A review. Biolog. Agric. Hortic. 2015, 31,1-17. [CrossRef]

34. Ertani, A.; Sambo, P.; Nicoletto, C.; Santagata, S.; Schiavon, M.; Nardi, S. The use of organic biostimulants in hot pepper plants to help low input sustainable agriculture. Chem. Biol. Technol. Agric. 2015, 2, 11. [CrossRef]

35. Crouch, I.J.; Van Staden, J. Evidence for the presence of plant growth regulators in commercial seaweed products. Plant Growth Regul. 1993, 13, 21-29. [CrossRef]

36. Blunden, G.; Jenkins, T.; Liu, Y.-W. Enhanced leaf chlorophyll levels in plants treated with seaweed extract. J. Appl. Phycol. 1996, 8, 535-543. [CrossRef]

37. Rayorath, P.; Jithesh, M.N.; Farid, A.; Khan, W.; Palanisamy, R.; Hankins, S.D.; Critchley, A.T.; Prithiviraj, B. Rapid bioassays to evaluate the plant growth promoting activity of Ascophyllum nodosum (L.) Le Jol. using a model plant, Arabidopsis thaliana (L.) Heynh. J. Appl. Phycol. 2008, 20, 423-429. [CrossRef]

38. Craigie, J.S. Seaweed extract stimuli in plant science and agriculture. J. Appl. Phycol. 2011, 23, 371-393. [CrossRef]

39. Sanderson, J.J.; Jameson, P.E.; Zabkiewicz, J.A. Auxin in a seaweed extract: Identification and quantification of indole-3acetic acid by gas chromatography-mass spectrometry. J. Plant Physiol. 1987, 129, 363-367. [CrossRef]

40. Oancea, F.; Velea, S.; Fãtu, V.; Mincea, C.; Ilie, L. Micro-algae based plant biostimulant and its effect on water stressed tomato plants. Rom. J. Plant Prot. 2013, 6, 104-117.

41. Mata, T.M.; Martins, A.A.; Caetano, N.S. Microalgae for biodiesel production and other applications: A review. Renew. Sustain. Energy Rev. 2010, 14, 217-232. [CrossRef]

42. Hultberg, M.; Carlsson, A.S.; Gustafsson, S. Treatment of drainage solution from hydroponic greenhouse production with microalgae. Bioresour. Technol. 2013, 136, 401-406. [CrossRef]

43. Brennan, L.; Owende, P. Biofuels from microalgae-A review of technologies for production, processing, and extractions of biofuels and co-products. Renew. Sustain. Energy Rev. 2010, 14, 557-577. [CrossRef]

44. Carvalho, A.P.; Meireles, L.A.; Malcata, X. Microalgal reactors: A review of enclosed system designs and performances. Biotechnol. Prog. 2006, 22, 1490-1506. [CrossRef]

45. Ugwu, C.U.; Aoyagi, H.; Uchiyama, H. Photobioreactors for mass cultivation of algae. Bioresour. Technol. 2008, 99, 4021-4028. [CrossRef]

46. Moheimani, N.R.; Borowitzka, M.A. The long-term culture of the coccolithophore Pleurochrysis carterae (Haptophyta) in outdoor raceway ponds. J. Appl. Phycol. 2006, 18, 703-712. [CrossRef]

47. Pushparaj, B.; Pelosi, E.; Tredici, M.R.; Pinzani, E.; Materassi, R. As integrated culture system for outdoor production of microalgae and cyanobacteria. J. Appl. Phycol. 1997, 9, 113-119. [CrossRef]

48. Moreno, J.; Vargas, M.A.; Rodriguez, H.; Rivas, J.; Guerrero, M.G. Outdoor cultivation of a nitrogen-fixing marine cyanobacterium, Anabaena sp. ATCC 33047. Biomol. Eng. 2003, 20, 191-197. [CrossRef]

49. Jiménez, C.; Cossío, B.R.; Niell, F.X. Relationship between physicochemical variables and productivity in open ponds for the production of Spirulina: A predictive model of algal yield. Aquaculture 2003, 221, 331-345. [CrossRef] 
50. Garcia-Gonzalez, M.; Moreno, J.; Canavate, J.P.; Anguis, V.; Prieto, A.; Manzano, C.; Florencio, F.J.; Guerrero, M.G. Conditions for open-air outdoor culture of Dunaliella salina in southern Spain. J. Appl. Phycol. 2003, 15, 177-184. [CrossRef]

51. Richmond, A.; Zhang, C.-W. Optimisation of a plate glass reactor for mass production of Nannochloropsis sp. outdoors. J. Biotechnol. 2001, 85, 259-269. [CrossRef]

52. Richmond, A. Open systems for the mass-production of photoautotrophic microalgae outdoors-physiological principles. J. Appl. Phycol. 1992, 4, 281-286. [CrossRef]

53. Laws, E.A.; Terry, K.L.; Wickman, J.; Chalup, M.S. A simple algal production systems designed to utilise the flashing light effect. Biotechnol. Bioeng. 1983, 25, 2319-2335. [CrossRef] [PubMed]

54. Radmann, E.M.; Reinehr, C.O.; Costa, J.A.V. Optimisation of the repeated batch cultivation of microalga Spirulina platensis in open raceway ponds. Aquaculture 2007, 265, 118-126. [CrossRef]

55. Fuentes, M.M.R.; Sanchez, J.L.G.; Sevilla, J.M.F.; Fernandez, F.G.A.; Perez, J.A.S.; Grima, E.M. Outdoor continuous culture of Porphyridium cruentum in a tubular photobioreactor: Quantitative analysis of the daily cyclic variation of culture parameters. J. Biotechnol. 1999, 70, 271-288. [CrossRef]

56. Acién, F.G.; Fernández Sevilla, J.M.; Sánchez Pérez, J.A.; Molina Grima, E.; Chisti, Y. Airlift-driven external-loop tubular photobioreactors for outdoor production of microalgae: Assessment of design and performance. Chem. Eng. Sci. 2001, 56, 2721-2732. [CrossRef]

57. Tredici, M.R.; Zitelli, G.C. Efficiency of sunlight utilisation: Tubular versus flat photobioreactors. Biotechnol. Bioeng. 1998, 57, 187-197. [CrossRef]

58. Chini Zittelli, G.; Lavista, F.; Bastianini, A.; Rodolfi, L.; Vicenzini, M.; Tredici, M.R. Production of eicosapentaenoic acid by Nannochloropsis sp. cultures in outdoor tubular photobioreactors. J. Biotechnol. 1999, 70, 299-312. [CrossRef]

59. Chini Zittelli, G.; Rodolfi, L.; Biondi, N.; Tredici, M.R. Productivity and photosynthetic efficiency of outdoor cultures of Tetraselmis suecica in annular columns. Aquaculture 2006, 261, 932-943. [CrossRef]

60. Ugwu, C.U.; Ogbonna, J.C.; Tanaka, H. Improvement of mass transfer characteristics and productivities of inclined tubular photobioreactors by installation of internal static mixers. Appl. Microbiol. Biotechnol. 2002, 58, 600-607. [CrossRef]

61. García-Malea, M.C.; Acién, F.G.; Fernández, J.M.; Cerón, M.C.; Molina, E. Continuous production of green cells of Haematococcus pluvialis: Modeling of the irradiance effect. Enzyme Microb. Technol. 2006, 38, 981-989. [CrossRef]

62. Cheng-Wu, Z.; Zmora, O.; Kopel, R.; Richmond, A. An industrial-sise flate plate glass reactor for mass production of Nannochloropsis sp. (Eustigmatophyceae). Aquaculture 2001, 195, 35-49. [CrossRef]

63. Degen, J.; Uebele, A.; Retze, A.; Schmid-Staiger, U.; Trosch, W. A novel airlift photobioreactor with baffles for improved light utilisation through the flashing light effect. J. Biotechnol. 2001, 92, 89-94. [CrossRef]

64. Rodolfi, L.; Chini Zittelli, G.; Bassi, N.; Padovani, G.; Biondi, N.; Bonini, G.; Tredici, M. Microalgae for oil: Strain selection, induction of lipid synthesis and outdoor mass cultivation in a low-cost photobioreactor. Biotechnol. Bioeng. 2009, 102, 100-112. [CrossRef]

65. Pulz, O. Photobioreactors: Production systems for phototrophic microorganisms. Appl. Microbiol. Biotechnol. 2001, 57, 287-293.

66. Richmond, A. Handbook of Microalgae Culture: Biotechnology and Applied Phycology; Blackwell Publishing: Oxford, UK, 2004; p. 566.

67. Huesemann, M.; Benemann, J.R. Biofuels from microalgae: Review of products, process and potential, with special focus on Dunaliella sp. In The Alga Dunaliella: Biodiversity, Physiology, Genomics and Biotechnology; Ben-Amotz, A., Polle, J.E.W., Subba Rao, V.D., Eds.; Science Publishers: Enfield, NH, USA, 2009.

68. Chisti, Y. Biodiesel from microalgae. Biotechnol. Adv. 2007, 25, 294-306. [CrossRef]

69. Wijffels, R.H.; Barbosa, M.J. An outlook on microalgal biofuels. Science 2010, 329, 796-799. [CrossRef]

70. Borowitzka, M.A. High-value products from microalgae-Their development and commercialisation. J. Appl. Phycol. 2013, 25, 743-756. [CrossRef]

71. Pragya, N.; Pandey, K.K.; Sahoo, P.K. A review on harvesting, oil extraction and biofuels production technologies from microalgae. Renew. Sustain. Energy Rev. 2013, 24, 159-171. [CrossRef]

72. Lee, Y.K. Microalgal mass culture systems and methods: Their limitation and potential. J. Appl. Phycol. 2001, 13, 307-315. [CrossRef] 
73. Detweiler, A.M.; Mioni, C.E.; Hellier, K.L.; Allen, J.J.; Carter, S.A.; Bebout, B.M.; Fleming, E.E.; Corrado, C.; Prufert-Bebout, L.E. Evaluation of wavelength selective photovoltaic panels on microalgae growth and photosynthetic efficiency. Algal Res. 2015, 9, 170-177. [CrossRef]

74. Gong, Y.; Jiang, M. Biodiesel production with microalgae as feedstock: From strains to biodiesel. Biotechnol. Lett. 2011, 33, 1269-1284. [CrossRef] [PubMed]

75. Zhang, J.; Wang, X.; Zhou, Q. Co-cultivation of Chlorella spp. and tomato in a hydroponic system. Biomass Bioenerg. 2017, 97, 132-138. [CrossRef]

76. Barone, V.; Puglisi, I.; Fragalà, F.; Piero, A.R.L.; Giuffrida, F.; Baglieri, A. Novel bioprocess for the cultivation of microalgae in hydroponic growing system of tomato plants. J. Appl. Phycol. 2019, 31, 465-470. [CrossRef]

77. Danesi, E.D.G.; Rangel-Yagui, C.O.; de Carvalho, J.C.M.; Sato, S. An investigation of effect of replacing nitrate by urea in the growth and production of chlorophyll by Spirulina platensis. Biomass Bioenerg. 2002, 23, 261-269. [CrossRef]

78. Colla, L.M.; Reinehr, C.O.; Reichert, C.; Costa, J.A.V. Production of biomass and nutraceutical compounds by Spirulina platensis under different temperature and nitrogen regimes. Bioresour. Technol. 2007, 98, 1489-1493. [CrossRef] [PubMed]

79. Ogbonda, K.H.; Aminigo, R.E.; Abu, G.O. Influence of temperature and $\mathrm{pH}$ on biomass production and protein biosynthesis in a putative Spirulina sp. Bioresour. Technol. 2007, 98, 2207-2211. [CrossRef] [PubMed]

80. Brown, M.R.; Jeffrey, S.W.; Volkman, J.K.; Dunstan, G.A. Nutritional properties of microalgae for mariculture. Aquaculture 1997, 151, 315-331. [CrossRef]

81. Kaplan, D.; Richmond, A.E.; Dubinsky, Z.; Aaronson, S. Algal nutrition. In Handbook of Microalgal Mass Culture; Richmond, A., Ed.; CRC Press: Boca Raton, FL, USA, 1986; pp. 147-198.

82. Levasseur, M.; Thompson, P.A.; Harrison, P.J. Physiological acclimation of marine phytoplankton to different nitrogen sources 1. J. Phycol. 1993, 29, 587-595. [CrossRef]

83. Fidalgo, J.P.; Cid, A.; Torres, E.; Sukenik, A.; Herrero, C. Effects of nitrogen source and growth phase on proximate biochemical composition, lipid classes and fatty acid profile of the marine microalga Isochrysis galbana. Aquaculture 1998, 166, 105-116. [CrossRef]

84. Yang, C.; Liu, H.; Li, M.; Yu, C.; Yu, G. Treating urine by Spirulina platensis. Acta Astronaut. 2008, 63, $1049-1054$. [CrossRef]

85. Aly, M.S.; Esawy, M.A. Evaluation of Spirulina platensis as bio stimulator for organic farming systems. J. Gen. Eng. Biotechnol. 2008, 6, 1-7.

86. Çelekli, A.; Yavuzatmaca, M. Predictive modeling of biomass production by Spirulina platensis as function of nitrate and $\mathrm{NaCl}$ concentrations. Bioresour. Technol. 2009, 100, 1847-1851. [CrossRef]

87. Czerpak, R.; Bajguz, A.; Piotrowska, A.; Dobrogowska, R.; Matejczyk, W.; Wieslawski, W. Biochemical activity of di- and polyamines in the green alga Chlorella vulgaris Beijerinck (Chlorophyceae). Acta Soc. Bot. Pol. 2003, 72, 19-24. [CrossRef]

88. Hourmant, A.; Mereau, N.; Penot, M.; Cann, C.; Caroff, J. Influence of polyamines on growth and metabolism of Dunaliella primolecta. Acta Bot. Neerl. 1994, 43, 129-136. [CrossRef]

89. Czerpak, R.; Krotke, A.; Mical, A. Comparison of stimulatory effect of auxins and cytokinins on protein, saccharides and chlorophylls content in Chlorella pyrenoidosa Chick. Pol. Arch. Hydrobiol. 1999, 46, 71-82.

90. Grima, E.M.; Belarbi, E.H.; Fernández, F.A.; Medina, A.R.; Chisti, Y. Recovery of microalgal biomass and metabolites: Process options and economics. Biotechnol. Adv. 2003, 20, 491-515. [CrossRef]

91. Shaaban, M.M.; El-Saady, A.K.M.; El-Sayed, A.E.K.B. Green microalgae water extract and micronutrients foliar application as promoters to nutrient balance and growth of wheat plants. J. Am. Sci. 2010, 6, 631-636.

92. Sharma, H.S.; Fleming, C.; Selby, C.; Rao, J.R.; Martin, T. Plant biostimulants: A review on the processing of macroalgae and use of extracts for crop management to reduce abiotic and biotic stresses. J. Appl. Phycol. 2014, 26, 465-490. [CrossRef]

93. García, J.R.; Fernández, F.A.; Sevilla, J.F. Development of a process for the production of l-amino-acids concentrates from microalgae by enzymatic hydrolysis. Bioresour. Technol. 2012, 112, 164-170. [CrossRef]

94. Joana Gil-Chávez, G.; Villa, J.A.; Fernando Ayala-Zavala, J.; Basilio Heredia, J.; Sepulveda, D.; Yahia, E.M.; González-Aguilar, G.A. Technologies for extraction and production of bioactive compounds to be used as nutraceuticals and food ingredients: An overview. Compr. Rev. Food Sci. Food Saf. 2013, 12, 5-23. [CrossRef]

95. Michalak, I.; Chojnacka, K.; Dmytryk, A.; Wilk, R.; Gramza, M.; Rój, E. Evaluation of supercritical extracts of algae as biostimulants of plant growth in field trials. Front. Plant Sci. 2016, 7, 1591. [CrossRef] 
96. Michalak, I.; Chojnacka, K. Algal extracts: Technology and advances. Eng. Life Sci. 2014, 14, 581-591. [CrossRef]

97. Vigani, M.; Parisi, C.; Rodríguez-Cerezo, E.; Barbosa, M.J.; Sijtsma, L.; Ploeg, M.; Enzing, C. Food and feed products from micro-algae: Market opportunities and challenges for the EU. Trends Food Sci. Technol. 2015, 42, 81-92. [CrossRef]

98. Coppens, J.; Grunert, O.; Van Den Hende, S.; Vanhoutte, I.; Boon, N.; Haesaert, G.; De Gelder, L. The use of microalgae as a high-value organic slow-release fertiliser results in tomatoes with increased carotenoid and sugar levels. J. Appl. Phycol. 2016, 28, 2367-2377. [CrossRef]

99. Hayashi, T.; Hayashi, K.; Maeda, M.; Kojima, I. Calcium spirulan, an inhibitor of enveloped virus replication, from a blue-green alga Spirulina platensis. J. Nat. Prod. 1996, 59, 83-87. [CrossRef]

100. He, M.; Wang, Z.; Tang, H. The chemical, toxicological and ecological studies in assessing the heavy metal pollution in Le An River, China. Water Res. 1998, 32, 510-518. [CrossRef]

101. Kumar, K.S.; Dahms, H.U.; Won, E.J.; Lee, J.S.; Shin, K.H. Microalgae-A promising tool for heavy metal remediation. Ecotoxicol. Environ. Saf. 2015, 113, 329-352. [CrossRef]

102. Tüzün, İ.; Bayramoğlu, G.; Yalçın, E.; Başaran, G.; Çelik, G.; Arıca, M.Y. Equilibrium and kinetic studies on biosorption of $\mathrm{Hg}(\mathrm{II}), \mathrm{Cd}(\mathrm{II})$ and $\mathrm{Pb}(\mathrm{II})$ ions onto microalgae Chlamydomonas reinhardtii. J. Environ. Manag. 2005, 77, 85-92. [CrossRef]

103. Mehta, S.K.; Gaur, J.P. Use of algae for removing heavy metal ions from waste water: Progress and prospects. Crit. Rev. Biotechnol. 2005, 25, 113-152. [CrossRef]

104. Gebser, B.; Pohnert, G. Synchronised Regulation of Different Zwitterionic Metabolites in the Osmoadaption of Phytoplankton. Mar. Drugs 2013, 11, 2168-2182. [CrossRef]

105. Spolaore, P.; Joannis-Cassan, C.; Duran, E.; Isambert, A. Commercial applications of microalgae. J. Biosci. Bioeng. 2006, 101, 87-96. [CrossRef] [PubMed]

106. Stirk, W.A.; Ördög, V.; Novák, O.; Rolèík, J.; Strnad, M.; Bálint, P.; Staden, J. Auxin and cytokinin relationships in 24 microalgal strains. J. Phycol. 2013, 49, 459-467. [CrossRef]

107. Stirk, W.A.; Bálint, P.; Tarkowská, D.; Novák, O.; Strnad, M.; Ördög, V.; van Staden, J. Hormone profiles in microalgae: Gibberellins and brassinosteroids. Plant Physiol. Biochem. 2013, 70, 348-353. [CrossRef]

108. Tate, J.J.; Gutierrez-Wing, M.T.; Rusch, K.A.; Benton, M.G. The effects of plant growth substances and mixed cultures on growth and metabolite production of green algae Chlorella sp.: A review. J. Plant Growth Regul. 2013, 32, 417-428. [CrossRef]

109. Kowalczyk, K.; Zielony, T.; Gajewski, M. Effect of aminoplant and asahi on yield and quality of lettuce grown on rockwool. In Biostimulators in Modern Agriculture. Vegetable Crop; Dąbrowski, Z.T., Ed.; Wieś Jutra: Warsaw, Poland, 2008; pp. 35-43.

110. González, A.; Castro, J.; Vera, J.; Moenne, A. Seaweed Oligosaccharides Stimulate Plant Growth by Enhancing Carbon and Nitrogen Assimilation, Basal Metabolism, and Cell Division. J. Plant Growth Regul. 2013, 32, 443-448. [CrossRef]

111. Yin, Y.; Wang, Z.Y.; Mora-Garcia, S.; Li, J.; Yoshida, S.; Asami, T.; Chory, J. BES1 accumulates in the nucleus in response to brassinosteroids to regulate gene expression and promote stem elongation. Cell 2002, 109, 181-191. [CrossRef]

112. Belkhadir, Y.; Yang, L.; Hetzel, J.; Dangl, J.L.; Chory, J. The growth-defense pivot: Crisis management in plants mediated by LRR-RK surface receptors. Trends Biochem. Sci. 2014, 39, 447-456. [CrossRef] [PubMed]

113. Karthikeyan, S.; Balasubramanian, R.; Iyer, C.S.P. Evaluation of the marine algae Ulva fasciata and Sargassum sp. for the biosorption of $\mathrm{Cu}$ (II) from aqueous solutions. Bioresour. Technol. 2007, 98, 452-455. [CrossRef]

114. Lu, Y.; Xu, J. Phytohormones in microalgae: A new opportunity for microalgal biotechnology? Trends Plant Sci. 2015, 20, 273-282. [CrossRef]

115. Tarakhovskaya, E.R.; Maslov, Y.I.; Shishova, M.F. Phytohormones in algae. Russ. J. Plant Physiol. 2007, 54, 163-170. [CrossRef]

116. Tarraf, S.A.; Talaat, I.M.; El-Sayed, A.E.K.B.; Balbaa, L.K. Influence of foliar application of algae extract and amino acids mixture on fenugreek plants in sandy and clay soils. Amino Acids 2015, 16, 19-58.

117. Woodward, A.W.; Bartel, B. Auxin: Regulation, action, and interaction. Ann. Bot. 2005, 95, 707-735. [CrossRef]

118. Muday, G.K.; Murphy, A.S. An emerging model of auxin transport regulation. Plant Cell 2002, 14, $293-299$. [CrossRef] 
119. Haberer, G.; Kieber, J.J. Cytokinins. New insights into a classic phytohormone. Plant Physiol. 2002, 128, 354-362. [CrossRef]

120. Tan, B.C.; Schwartz, S.H.; Zeevaart, J.A.; McCarty, D.R. Genetic control of abscisic acid biosynthesis in maise. Proc. Natl. Acad. Sci. USA 1997, 94, 12235-12240. [CrossRef]

121. Maršálek, B.; Zahradníčková, H.; Hronková, M. Extracellular abscisic acid produced by cyanobacteria under salt stress. J. Plant Physiol. 1992, 139, 506-508. [CrossRef]

122. McAdam, S.A.; Brodribb, T.J. Linking turgor with ABA biosynthesis: Implications for stomatal responses to vapor pressure deficit across land plants. Plant Physiol. 2016, 171, 2008-2016. [CrossRef]

123. Lu, Y.; Tarkowská, D.; Turečková, V.; Luo, T.; Xin, Y.; Li, J.; Wang, Q.; Jiao, N.; Strnad, M.; Xu, J. Antagonistic roles of abscisic acid and cytokinin during response to nitrogen depletion in oleaginous microalga Nannochloropsis oceanica expand the evolutionary breadth of phytohormone function. Plant J. 2014, 80, 52-68. [CrossRef]

124. Bose, S.K.; Yadav, R.K.; Mishra, S.; Sangwan, R.S.; Singh, A.K.; Mishra, B.; Srivastava, A.K.; Sangwan, N.S. Effect of gibberellic acid and calliterpenone on plant growth attributes, trichomes, essential oil biosynthesis and pathway gene expression in differential manner in Mentha arvensis L. Plant Physiol. Biochem. 2013, 66, 150-158. [CrossRef]

125. Stirk, W.A.; Novák, O.; Hradecká, V.; Pĕnčík, A.; Rolčík, J.; Strnad, M.; Van Staden, J. Endogenous cytokinins, auxins and abscisic acid in Ulva fasciata (Chlorophyta) and Dictyota humifusa (Phaeophyta): Towards understanding their biosynthesis and homoeostasis. Eur. J. Phycol. 2009, 44, 231-240. [CrossRef]

126. Tsavkelova, E.A.; Klimova, S.Y.; Cherdyntseva, T.A.; Netrusov, A.I. Hormones and hormone-like substances of microorganisms: A review. Appl. Biochem. Microbiol. 2006, 42, 229-235. [CrossRef]

127. Stirk, W.A.; Bálint, P.; Tarkowská, D.; Novák, O.; Maróti, G.; Ljung, K.; Turečková, V.; Strnad, M.; Ördög, V.; Van Staden, J. Effect of light on growth and endogenous hormones in Chlorella minutissima (Trebouxiophyceae). Plant Physiol. Biochem. 2014, 79, 66-76. [CrossRef]

128. Plaza, B.M.; Gómez-Serrano, C.; Acién-Fernández, F.G.; Jimenez-Becker, S. Effect of microalgae hydrolysate foliar application (Arthrospira platensis and Scenedesmus sp.) on Petunia x hybrida growth. J. Appl. Phycol. 2018, 30, 2359-2365. [CrossRef]

129. Biancardi, E.; McGrath, J.M.; Panella, L.W.; Lewellen, R.T.; Stevanato, P. Sugar beet. In Handbook of Plant Breeding, Tuber and Root Crops; Bradshaw, J., Ed.; Springer: New York, NY, USA, 2010; Volume 4, pp. 173-219.

130. Ronga, D.; Rizza, F.; Badeck, F.W.; Milc, J.; Laviano, L.; Montevecchi, G.; Pecchioni, N.; Francia, E. Physiological responses to chilling in cultivars of processing tomato released and cultivated over the past decades in Southern Europe. Sci. Hortic. 2018, 231, 118-125. [CrossRef]

131. Munns, R.; Tester, M. Mechanisms of salinity tolerance. Annu. Rev. Plant Biol. 2008, 59, 651-681. [CrossRef]

132. Goycovic-Cortez, V.; Saavedra del Real, G. Some effects of salinity on the tomato cultivars and agronomic practices in its managing. Idesia 2007, 25, 47-58.

133. Van Oosten, M.J.; Pepe, O.; De Pascale, S.; Silletti, S.; Maggio, A. The role of biostimulants and bioeffectors as alleviators of abiotic stress in crop plants. Chem. Biol. Technol. Agric. 2017, 4, 5. [CrossRef]

134. Vernieri, P.; Borghesi, E.; Ferrante, A.; Magnani, G. Application of biostimulants in floating system for improving rocket quality. J. Food Agric. Environ. 2005, 3, 86.

135. Abd El-Baky, H.H.; El-Baz, F.K.; El Baroty, G.S. Enhancing antioxidant availability in wheat grains from plants grown under seawater stress in response to microalgae extract treatments. J. Sci. Food Agric. 2010, 90, 299-303. [CrossRef]

136. Guzmán-Murillo, M.A.; Ascencio, F.; Larrinaga-Mayoral, J.A. Germination and ROS detoxification in bell pepper (Capsicum annuum L.) under $\mathrm{NaCl}$ stress and treatment with microalgae extracts. Protoplasma 2013, 250, 33-42. [CrossRef]

137. La Torre, A.; Battaglia, V.; Caradonia, F. An overview of the current plant biostimulant legislations in different European Member States. J. Sci. Food Agric. 2016, 96, 727-734. [CrossRef]

138. Caradonia, F.; Battaglia, V.; Righi, L.; Pascali, G.; La Torre, A. Plant biostimulant regulatory framework: Prospects in europe and current situation at international level. J. Plant Growth Regul. 2018. [CrossRef]

139. Mulbry, W.; Kondrad, S.; Pisarro, C. Biofertilisers from algal treatment of dairy and swine manure effluents. J. Veg. Sci. 2007, 12, 107-125. 
140. Schreiber, C.; Schiedung, H.; Harrison, L.; Briese, C.; Ackermann, B.; Kant, J.; Schrey, S.D.; Hofmann, D.; Singh, D.; Ebenhöh, O.; et al. Evaluating potential of green alga Chlorella vulgaris to accumulate phosphorus and to fertilise nutrient-poor soil substrates for crop plants. J. Appl. Phycol. 2018, 30, 2827-2836. [CrossRef]

141. Shaaban, M.M.; El-Fouly, M.M.; Abdel-Maguid, A.A. Zinc-Boron relationship in wheat plants grown under low or high levels of calcium carbonate in the soil. Pak. J. Biol. Sci. 2004, 7, 633-639.

142. Shaaban, M.M.; Loehnertz, O.; El-Fouly, M.M. Grapevine genotypic tolerance to lime and possibility of chlorosis recovery through micronutrients foliar application. Int. J. Bot. 2007, 3, 179-187.

143. Shaaban, M.M.; Hussein, M.M.; El Saady, A.M. Nutritional status in shoots of barley genotypes as affected by salinity of irrigation water. Am. J. Plant Physiol. 2008, 3, 89-95. [CrossRef]

144. Aulakh, M.S.; Malhi, S.S. Interactions of nitrogen with other nutrients and water: Effect on crop yield and quality, nutrient use efficiency, carbon sequestration, and environmental pollution. Adv. Agron. 2005, 86, 341-409.

145. Marschner, H. Mineral Nutrition of Higher Plants, 2nd ed.; Academic Pres: Boston, MA, USA, 1995.

146. Hall, J.L.; Williams, L.E. Transition metal transporters in plants. J. Exp. Bot. 2003, 54, 2601-2613. [CrossRef]

147. Salama, Z.A.; Shaaban, M.M. Growth, nutrient status and some oxidases enzyme activity of cucumber plants as affected by sodium chloride salinity. J. Agric. Sci. Mansoura Univ. 2000, 25, 2065-2074.

148. El-Fouly, M.M.; Shaaban, M.M.; El-Khdraa, T.F. Soil and plant nutritional status in fruit orchards in Syria. Acta Agron. Hung. 2008, 56, 363-370. [CrossRef]

149. Faheed, F.A.; Fattah, Z.A. Effect of Chlorella vulgaris as Biofertiliser on Growth Parameters and Metabolic Aspects of Lettuce Plant. J. Agric. Soc. Sci. 2008, 4, 165-169.

150. Paudel, Y.P.; Pradhan, S.; Pant, B.; Prasad, B.N. Role of blue green algae in rice productivity. Agric. Biol. J. N. Am. 2012, 3, 332-335. [CrossRef]

151. Shalaby, T.A.; El-Ramady, H. Effect of foliar application of bio-stimulants on growth, yield, components, and storability of garlic (Allium sativum L.). Aust. J. Crop Sci. 2014, 8, 271.

152. Barone, V.; Baglieri, A.; Stevanato, P.; Broccanello, C.; Bertoldo, G.; Bertaggia, M.; Cagnin, M.; Pizzeghello, D.; Moliterni, V.M.C.; Mandolino, G.; et al. Root morphological and molecular responses induced by microalgae extracts in sugar beet (Beta vulgaris L.). J. Appl. Phycol. 2018, 30, 1061-1071. [CrossRef]

153. Tripathi, R.D.; Dwivedi, S.; Shukla, M.K.; Mishra, S.; Srivastava, S.; Singh, R.; Rai, U.N.; Gupta, D.K. Role of blue green algae biofertiliser in ameliorating the nitrogen demand and fly-ash stress to the growth and yield of rice (Oryza sativa L.) plants. Chemosphere 2008, 70, 1919-1929. [CrossRef]

154. Lachman, J.; Orsak, M.; Pivec, V.; Kratochvilova, D. Anthocyanins and carotenoids-major pigments of roses. Hort. Sci. 2001, 28, 33-39.

155. Chen, J. The combined use of chemical and organic fertilisers and/or biofertiliser for crop growth and soil fertility. In International Workshop on Sustained Management of the Soil-Rhizosphere System for Efficient Crop Production and Fertiliser Use; Land Development Department: Bangkok, Thailand, 2006; p. 20.

156. Stadler, C.; von Tucher, S.; Schmidhalter, U.; Gutser, R.; Heuwinkel, H. Nitrogen release from plant-derived and industrially processed organic fertilisers used in organic horticulture. J. Plant Nutr. Soil Sci. 2006, 169, 549-556. [CrossRef]

157. Sonneveld, C.; Voogt, W. Plant Nutrition of Greenhouse Crops; Springer: New York, NY, USA, 2009; pp. $393-403$.

158. Hagassou, D.; Francia, E.; Ronga, D.; Buti, M. Blossom end-rot in tomato (Solanum lycopersicum L.): A multi-disciplinary overview of inducing factors and control strategies. Sci. Hortic. 2009, 249, 49-58. [CrossRef]

159. Magán, J.J.; Gallardo, M.; Thompson, R.B.; Lorenzo, P. Effects of salinity on fruit yield and quality of tomato grown in soil-less culture in greenhouses in Mediterranean climatic conditions. Agric. Water Manag. 2008, 95, 1041-1055.

160. Borgognone, D.; Colla, G.; Rouphael, Y.; Cardarelli, M.; Rea, E.; Schwarz, D. Effect of nitrogen form and nutrient solution $\mathrm{pH}$ on growth and mineral composition of self-grafted and grafted tomatoes. Sci. Hortic. 2013, 149, 61-69. [CrossRef]

161. Misra, S.; Kaushik, B.D. Growth promoting substances of cyanobacteria. In vitamins and their influence on rice plant. Proc. Indian Natl. Sci. Acad. Part B Biol. Sci. 1989, 55, 295-300.

162. Singh, V.P.; Trehan, K. Effect of extracellular products of Aulosira fertilissima on the growth of rice seedlings. Plant Soil 1973, 38, 457-464. [CrossRef] 
163. Cai, T.; Ge, X.; Park, S.Y.; Li, Y. Comparison of Synechocystis sp. PCC6803 and Nannochloropsis salina for lipid production using artificial seawater and nutrients from anaerobic digestion effluent. Bioresour. Technol. 2013, 144, 255-260. [CrossRef] [PubMed]

164. Arif, M.; Khan, M.A.; Akbar, H.; Ali, S. Prospects of wheat as a dual purpose crop and its impact on weeds. Pak. J. Weed Sci. Res. 2006, 12, 13-17.

165. Hellal, F.A.; Taalab, A.S.; Safaa, A.M. Influence of nitrogen and boron nutrition on nutrient balance and Sugar beet yield grown in calcareous soil. Ozean J. Appl. Sci. 2009, 2, 1-10.

166. Battacharyya, D.; Zamani Babgohari, M.; Rathor, P.; Prithiviraj, B. Seaweed extracts as biostimulants in horticulture. Sci. Hortic. 2015, 196, 39-48. [CrossRef]

167. Marschner, H. Mineral Nutrition of Higher Plants, 3rd ed.; Academic Press: London, UK, 2012.

168. Oliveira, J.; Mógor, G.; Mógor, A. Produtividade de beterraba em função da aplicação foliar de biofertilisante. Cadernos de Agroecologia 2013, 8, 1-4.

169. Zarrouk, C. Contribution a L'etude D'une Cyanobacterie: Influence de Divers Facteurs Physiques et Chimiques sur la Croissance et la Photosynthese de Spirulina Maxima (Setchell et Gardner) Geitler. Ph.D. Thesis, University of Paris, Paris, France, 1966.

170. Guillard, R.R.L. Culture of phytoplankton for feeding marine invertebrates. In Cultures of Marine Invertebrate Animals; Smith, W.L., Chanley, M.H., Eds.; Plenum Press: New York, NY, USA, 1975; pp. $29-60$.

171. Zucconi, F.; Pera, A.; Forte, M.; De Bertoldi, M. Evaluating toxicity of immature compost. BioCycle 1981, $22,54-57$.

172. Tiquia, S.M.; Tam, N.F.Y. Elimination of phytotoxicity during co-composting of spent pig-manure sawdust litter and pig sludge. Bioresour. Technol. 1998, 65, 43-49. [CrossRef]

173. De Macedo, D.M.; de Barbosa, C.Y.; Pedrosa Brandão, R.M.; das Graças, M.; Gálvez, A.O.; Souza Bezerra, R. Evaluation of antioxidant and antibacterial capacity of green microalgae Scenedesmus subspicatus. Food Sci. Technol. Int. 2019. [CrossRef]

174. Pradhan, J.; Das, S.; Das, B.K. Antibacterial activity of freshwater microalgae: A review. Afr. J. Pharm. Pharmacol. 2014, 8, 809-818.

175. Ghasemi, Y.; Moradian, A.; Mohagheghzadeh, A.; Shokravi, S.; Morowvat, M.H. Antifungal and antibacterial activity of microalgae collected from paddy fields of Iran: Characterisation of antimicrobial activity of Chroococcus dispersus. J. Biol. Sci. 2007, 7, 904-910.

176. Pina-Pérez, M.C.; Rivas, A.; Martínez, A.; Rodrigo, D. Antimicrobial potential of macro and microalgae against pathogenic and spoilage microorganisms in food. Food Chem. 2017, 235, 34-44. [CrossRef] [PubMed] 